\title{
Orthodontic Forensic Science: The Unseen Part of our Profession
}

\author{
Sunil Kumar Rath ${ }^{1^{*}}$ and Subhashree Manaswini Panda ${ }^{2}$
}

Department of Periodontics, SCB Dental College, Odisha, India

*Corresponding author: Sunil Kumar Rath, Department of Periodontics, SCB Dental College, 753007, Odisha, India, Tel: 7376904509; E-mail: vikybds@gmail.com

Received date: April 01, 2017; Accepted date: April 21, 2017; Published date: April 27, 2017

Copyright: (c) 2017 Rath SK, et al. This is an open-access article distributed under the terms of the Creative Commons Attribution License, which permits unrestricted use, distribution, and reproduction in any medium, provided the original author and source are credited.

\begin{abstract}
Forensic odontology is a new concept in India. It has been recognized as a graduate course since 2007. Various fields of dentistry has correlation with this new branch, similarly orthodontist too has an important role in forensic science. In this article it has been emphasized that the records of orthodontist has a significant role in victim and culprit identification. A brief review of history of orthodontic in forensic and bite mark has been discussed.
\end{abstract}

Keywords: Forensic odontology; Bite marks; Amyloglyphics; Chelioscopy; Rugoscopy

\section{Introduction}

Orthodontics is the part of dentistry that deals with the prevention, supervision and guidance of the development of masticatory apparatus, correction of abnormal occlusion including the desirable tooth movement and establishment of functional and aesthetic harmony of face as a whole [1]. As the treatment time is longer and planning is complex, orthodontist ought to take several records during pre-treatment planning, undergoing treatment and post treatment phase. Mostly the records consist of patient's history, dental cast, extra oral and intraoral photographs and X-rays (at least Orthopantomogram (OPG) and lateral Cephalogram). The records can be considered as the comprehensive document that contains all data about patient's identification.

Forensic dentistry in science represents the overlap between the dental and the legal professions. The stored materials, which cannot be putrefied, can be utilized during lawsuits against dentists, identification procedure of cadavers having only skeleton or which undergone putrefaction [2-5]. Considering the responsibility of orthodontists in the practice of their profession and the richness of information found in orthodontic records, this article describes a forensic case of an individual whose remains were incinerated and whose identity was positively established using information from a panoramic radiograph and intraoral photographs taken during an orthodontic treatment.

\section{History}

It was nineteenth century when Oscar AmoGdo (1863-1945) who is considered as the father of forensic dentistry wrote the $1^{\text {st }}$ book named "L Art Dewtaire en Me'decine Legale" (1898). In the twentieth century book, Krogman's text, (1961) The Human Skeleton in Forensic Medicine was published, the value of orthodontic diagnostic aids in forensic odontology received recognition. Cephalometric radiography has been validated as a positive tool in identification by Hassouni [6]. Furuhata $\mathrm{T}$ published a book on forensic odontology in Japanese language in 1963; the English edition named "Forensic Odontology" was published in 1967. That book brought the importance of orthodontic removable appliances as a factor in identification of victims. The difference in designing appliances by different orthodontist leads to the complete record maintenance. Furthermore, the classification and the details of the malocclusion can be helpful in identification of victims. A book named 'Handbook of dental identification: Technique in forensic dentistry' was published by Lester and Luntz P in the year 1973.

The first ever literature in reputed orthodontic speciality journal was published in American journal of orthodontics in 1974 by Salzman [7].

Thereafter many more literatures had been written regarding the relationship of orthodontics and forensic dentistry. In orthodontic point of view, the sequential record keeping is considered as the gold standard for treatment planning, and the forensic part deals with the ante-mortem records for identification. So here in these following sections of this article various correlations re discussed. This study shows an overall picture of all the procedures in orthodontics; those can have implication in Forensic science.

\section{Record Keepings}

As the complexity of the cases increases, the time duration of treatment increases. So the no of records that orthodontist takes increases during the treatment duration. The records usually behave as an aid in diagnosis, treatment planning and subsequent procedures. These records notated as dental charts. It is a comprehensive document that includes data with identification of patient and history, answers to some interrelated health questionnaires, clinical examination of general physical health and extra- and intraoral exams, specific or multiple treatment plan chosen, and finally the patient's consent form. Patient records are also supplemented by various tests required by the orthodontic treatment, such as radiographs, plaster impressions, photographs (intra and extra oral), radiograph tracings, and other specific diagnostic aids. These stored records help the orthodontist to re-evaluate any progress in the treatment in a spotted time and can be legal aid in front of judiciary [8].

There are various terms and conditions in different states for storage of the dental clinical records. According to National Health Service (NHS) UK Terms, dental records should be stored for a period of two years. There are some conditions where the records should be stored for indefinite for a period of 30 years. In a private practice the records should be stored for 11 years after the last entry for adults; 11 years 
Page 2 of 4

after the last entry for children or until they reach age 25 years, whichever is the longer [3].

In Forensic Dentistry, the importance of these stored materials is associated with both issues of professional defence, in cases of law suits against dentists, and the identification of skeletonised, putrefied or incinerated cadavers. Considering the responsibility of orthodontists in the practice of their profession and the richness of information found in orthodontic records, forensic case of an individual whose remains were incinerated can easily assessed using information from a panoramic radiograph and intraoral photographs taken during orthodontic treatment [9].

\section{Bite Marks}

MacDonald defined 'Bite mark' as a mark made by the teeth either alone or in combination with other mouth parts [10].

In forensic odontology, the part that deals with Indexing and identification of bite marks has very high importance in terms of evidentiary value. In the Indian context the number of population seeking orthodontic treatment is comparatively low as compared to western population. It could be considered as a limitation of orthodontics in Indian Orthodontic Forensic odontology, but the good indication is that the number is currently increasing in India.

Although the limitations with these above named methods are less, the discrepancies associated with them ought to be weighed cautiously to make forensic odontology a more accurate, reliable, and reproducible investigatory science.

Bite marks are produced mainly through two aspects $[11,12]$.

- As a result of sexual or physical assault by an adult on a child, rape or attempted rape, quarrels and fights among people

- May occur during self-defence when defending against aggressive animal or self-inflicted as tongue bite in epileptic fits or fall from heights

Mac Donald's etiological classification of bite marks [10].

- Pressure marks of tooth caused by insicial edge of anterior teeth.

- Pressure marks of tongue seen as impression of the palatal surface.

- Scratches and abrasions that can indicate irregularities in shape of teeth such as tooth fractures, restorations or attrition during scrapping.

- Multiple bite marks or/with a combination of a,b,c.

Gustafson's clinical classification [13]

- Well defined bite mark may be due to sadistic or sexual bite as these are made slowly

- Aggressive bite where bite is made quickly with force caused by scribing across the tissue.

- Most aggressive bite results in tissue being bitten off usually and involves ears, nose, and nipples.

American Board of Forensic Odontology (ABFO) guidelines [14] shows various classifications of bite marks according to the relationship of the jaws, the form and size of arches, missing teeth, spacing between teeth, presence of supernumerary teeth, observed rotations of teeth, the width of teeth, and presence of special features such as fractures and ridges.

\section{Presentation of Bite Mark Injuries}

Typical cases are presented as a semi-circular injury which comprises of two separate arcs (one from the upper teeth, the other from the lower) with either a central area absent of injury, or with a diffuse bruise present.

Factors to be considered during bite mark examination are

- The force by which the original injury was inflicted

- The anatomical location bitten

- The time elapsed between infliction and record

ABFO guideline says there may be four types of conclusion regarding bite mark examination. These are:

- Exclusion - The injury is not a bite mark.

- Possible bite mark - An injury showing a pattern that may or may not be caused by teeth could be caused by other factors but biting cannot be ruled out.

- Probable bite mark - The pattern strongly suggests or supports origin from teeth but could conceivably be caused by something else.

- Definite bite mark - There is no reasonable doubt that teeth created the pattern.

The first case solved by bite mark identification was the famous "Salem Witch Trials" in 1692 in United States. "Ted Bundy" killed numerous people between 1973 and 1978 but was finally tried for the murder of Lisa Levy in Florida State University, through the bite marks that he inflicted on her body [15].

\section{Study of Palatal Rugae (Rugoscopy)}

Palatal rugae, the ridges in the anterior part of palate behind incisive papilla, are recognized as a forensic tool in the year 1889 by Harrison Allen. These have different pattern namely curved, straight, wavy, and branched. In the instances, where post-mortem dental identification is not possible, as in edentulous mouths, palatal rugae can be used as supplement. This can be slightly altered during orthodontic treatment [16].

According to Kapali et al. [17] denture wear, tooth malposition, and palatal pathology can alter the patterns; reliability of these rugae pattern identification is questioned.

\section{Examination of Lip Prints (Chieloscopy)}

The genetically determined elevation, depression pattern in the external surface of the lip is the characteristic of a particular person and is known as lip prints. It does not change in pattern since birth, and can give significance, in number of people involved, cosmetics used; so socioeconomic status, ethnicity [18].

The exposed part of lip is usually chosen for impression taking. As the lip is vulnerable for change after death, it is better to record the impression within 24 hour.

\section{Examination of Tooth Prints (Ameloglyphics)}

It is the study of enamel rod end pattern. The undulating and intertwining path of Ameloblast during deposition of enamel, leads to a unique feature. This is reflected on the outer surface of the enamel as patterns of the ends of a series of adjacent enamel rods. This term is 
coined as Ameloglyphics by Manjunath et al. [19] and could aid as an identification tool in decomposed or burned bodies as enamel can resist decomposition.

Although the limitations with these above named methods are less, the discrepancies associated with them ought to be weighed cautiously to make forensic odontology a more accurate, reliable, and reproducible investigatory science.

\section{Radiographs}

The radiograph taken during various orthodontic procedures includes IOPA,OPG, cephalograms, denta-scan, CBCT etc. These have an advantage that they can be stored for a long time without any distortion, particularly if digital image were taken. In mass disasters cases where victims undergo decomposition, radiographs are the only available biometric method. With this evidence various morphological and pathological alterations of tooth as well as the facial skeleton can be viewed and compared to post-mortem data [20].

\section{Photograph}

Photographs are one of the essential diagnostic aids in orthodontics. There are at least 5 intraoral and 5 extra oral views that an orthodontist should take before planning any treatment. This also has an added advantage that can be stored for long time and can be analysed via software. Considering the limitation of $2 \mathrm{D}$ photographs new software has been developed through a 3 dimensional view can be taken. Mere colour change can be taken care of after the victims shape is identified, but this property is a limitation of $3 \mathrm{D}$ photographs.

\section{Example of a Case Held by an Orthodontist as a Forensic Expert}

In the early months of 1994 in which numerous human remains were exhumed in connection with what came to be known as the 'Cromwell Street murders' or the 'Frederick and Rosemary West' case. In the case, a young female was murdered and some of her teeth were missing, potentially presenting difficulties for comparison with information available at the time of her death. Orthodontist at the Forensic Dental Laboratories at Cardiff used high resolution photographs of the skull and superimposed over the females face. Moreover, they also replaced a labially tipped upper lateral incisor and finally proved the skull to be the same as that of the missing girl.

In dental literatures we can find various scientific articles:

The following case has been documented in Scielo orthodontic journal. A completely destroyed, burned remains of a human being was found inside a car During forensic evaluation of the crime scene, post-mortem and radiographic exams in the Forensic Department, it was found that the victim had a fixed orthodontic appliance, supernumerary teeth in all quadrants, partially erupted third molars and amalgam restorations in some surfaces of several teeth.

Fingerprint identification was not possible due to destroyed soft tissue. The orthodontic treatment chart was collected and the photograph of the victim was compared with ante mortem data and identification was confirmed [9].

In the next case; a skeleton was found having braces in Brazil. The origin was confirmed through the skull shape that he was of Caucasian origin, age accessed through dental radiographs. The family who searched for a missing portion was called and asked about the orthodontic records. Finally this person was identified [21].

In the present day the software (eg. Dolphin), which orthodontists are using, for their treatment planning, which enables them to form out the face reconstruction with the jaws in various positions, can be used for the identification of victims with post-mortem record with the use of data available from various growth studies.

\section{Conclusion}

Routine pre-treatment diagnostic records taking is ingrained in the orthodontist from the very first days of the post graduate training. These includes case history recording, clinical photograph of intra and extra oral with complete clinical and relevant medical examination. Those radiographic study has both cephalic and facial index and very vital in anthropometric data collection.

Extensive knowledge of the Orthodontist about the various aspects of the teeth position, angulations, head shape, growth, age assessment along with knowledge of inter canine and inter molar width and various aspects regarding implication of $2 \mathrm{D}$ and $3 \mathrm{D}$ radiographs, gives him recognized position in the field of forensic odontology.

Cases where it is impossible to do identification with the soft tissue because of putrefied body, an orthodontist can deal with the skeletal and dental remains; which are the maxilla, mandible, the dentition, and cranial base, vertebrae and finger $\mathrm{X}$-ray.

Orthodontists should be advised to take lip print during their record taking procedure.

The process of tracing cephalograms in which maxilla, mandible and cranial base, are accessed through various planes and analysed to identify the deviation from normal, can readily help the forensic odontologist to match with the post mortem records of the individual.

With the advancement of various technology an orthodontist is very much satisfy as a forensic expert for various undiagnosed victim identification.

\section{References}

1. http://www.rguhs.ac.in/Authoritysection/Revised\%20Ordinance $\% 20$ governing\%20MDS\%20Course $\% 20$ from $\% 20$ the $\% 20$ academic \%20year\%20\%202009-10\%20onwards.doc

2. Department of health (2009) Records management (Part 2), NHS Code of Practice.

3. Ramos DIA, Daruge Júnior E, Daruge E, Antunes FCM, Meléndez BVC, et al. (2005) Dental transposition and its ethical and legal implications. Rev ADM 62: 185-190.

4. Silva RF, Pereira SDR, Daruge E, Daruge Júnior E, Francesquini JL (2004) The reliability of odontolegal examination in human identification. Robrac 13: 46-50.

5. Silva RF, Cruz BVM, Daruge Júnior E, Daruge E, Francesquini JL (2005) The Importance of dental documentation in human identification. Acta Odontol Venez 43: 67-74.

6. Hassouni R (1960) Identification of war (lead by means of roentgenographic cephalometry. Tech Rep.

7. Salzman JA (1974) Editorial: Orthodontics in forensic odontology. Am J Orthod 65: 647-648.

8. Paranhos LR, Magalhães MPM, Francio J, Terada HH, Rosário HD, et al. (2013) Time of guard of orthodontic records versus legal time for their prescription. Dental Press J Orthod 18: 113-117. 
Citation: Rath SK, Panda SM (2017) Orthodontic Forensic Science: The Unseen Part of our Profession . J Forensic Res 8: 378. doi:

9. Silva RF, Chaves P, Paranhos LR, Lenza MA, Daruge Júnior E (2011) Use of orthodontic records in human identification. Dental Press J Orthod 16: 52-57.

10. MacDonald DG (1979) Bite marks, recognition and interpretation. J ForenSci 14: 229.

11. Clark DH (1980) Bite marks in tissue and in inanimate objects: analysis and comparison. In: Practical Forensic Odontology (3rd Edtn). Wright, UK.

12. Onmura T (1968) Examination of bite wounds in reference to a rape and murder case of a young girl. ActaCrim Med Deg Jap 34: 51

13. Gustafson G (1966) Forensic odontology. Staples Press, London, UK.

14. http://www.abfo.org/resources/id-bitemark-guidelines

15. https://sites.google.com/site/tedbundythelastbitemark/evidence

16. Paliwal A, Wanjari S, Parwani R (2010) Palatal rugoscopy: Establishing identity. J Forensic Dent Sci 2: 27-31.
17. Kapali S, Townsend G, Richards L, Parish T (1997) Palatal rugaepatterns in australian aborigines and caucasians. Aust Dent J 42: 129-133.

18. Kulkarni N, Vasudevan S, Shah R, Rao P, Balappanavar AY (2012) Cheiloscopy: A new role as a marker of sagittal jaw relation. J Forensic Dent Sci 4: 6-12.

19. Manjunath K, Sriram G, Saraswathi TR, Sivapathasundharam B (2008) Enamel rod end patterns: A preliminary study using acetate peel technique and automated biometrics. J Forensic Odontol 1: 33-35

20. Sholl SA, Moody GH (2001) Evaluation of dental radiographic identification: An experimental study. Forensic Sci Int 115: 165-169.

21. Terada ASS, de Araujo LG, Silviera PLR, Guimarães TCP, Silva RHA (2014) Orthodontic use of documentation in identification of a skeletonised body in legal practice. Int J Odontostomat 8: 41-46. 